•神农架世界自然遗产地专题・

\title{
神农架世界自然遗产地的全球突出 普遍价值及其保护
}

\author{
谢宗强* 申国珍 周友兵 㚞大勇 徐文婷 高贤明 \\ 杜彦君 熊高明 赵常明 祝 燕 赖江山
}

(中国科学院植物研究所植被与环境变化国家重点实验室, 北京 100093)

\begin{abstract}
摘要: 自然保护地是生物多样性及其生物生态过程保护的最有效手段, 世界自然遗产地是全球最具有保护价值的 自然保护地。神农架世界自然遗产地以其丰富的动植物多样性和独特的生物生态过程, 维持着北亚热带山地生态 系统的功能和稳定性。目前, 尚缺乏对神农架世界自然遗产地全球突出普遍价值的深入研究和论证, 仍不清楚其 突出普遍价值及其在全球的代表性。本研究在收集整理神农架历史文献资料的基础上，基于对神农架地区长达近 20 年的调查研究和数据积累, 依据 “实施《世界遗产公约》操作指南”, 从动植物多样性及其栖息地、生物群落及 其生物生态学过程等方面, 分析论证了神农架世界自然遗产地的全球突出普遍价值。神农架保存了完好的原始常 绿落叶阔叶混交林, 典型代表并展示了北半球常绿落叶阔叶混交林生态系统的生物生态学过程, 拥有北亚热带典 型的山地垂直自然带谱, 在东方落叶林生物地理省具有唯一性和代表性; 是温带植物区系分化、发展和集散的重 要地区和世界上落叶木本植物最丰富的地区, 突出反映了北亚热带生物群落的生物进化与演替的进程; 是众多古 老子遗物种的避难所, 也是国际珍稀濒危物种和中国特有种的重要栖息地。研究结果表明, 神农架世界自然遗产 地在生物多样性、生态系统类型、生物演化等方面为全球同纬度杰出代表。本研究明确了神农架世界自然遗产地 在全球背景下的突出普遍价值, 为科学合理地监测和保护全球同纬度地区北亚热带生物多样性和生态系统功能提 供了科学依据。
\end{abstract}

关键词：山地垂直带谱; 落叶木本植物; 廊道-踏脚石-通道; 生物生态学过程; 生物多样性及其栖息地

\section{The outstanding universal value and conservation of the Shennongjia World Natural Heritage Site}

Zongqiang Xie*, Guozhen Shen, Youbing Zhou, Dayong Fan, Wenting Xu, Xianming Gao, Yanjun Du, Gaoming Xiong, Changming Zhao, Yan Zhu, Jiangshan Lai

State Key Laboratory of Vegetation and Environment Change, Institute of Botany, Chinese Academy of Sciences, Beijing 100093

\begin{abstract}
World Natural Heritage site is recognized globally as the pinnacle of natural protected areas that are the cornerstones of biodiversity conservation. The World Natural Heritage of Shennongjia represents one of the worldwide biodiversity hotspots. But, until now, it has not been clear how outstanding the universal value of Shennongjia is worldwide, and this study presents one of the most compelling challenges to conservation efforts. Here, we compiled literature and conducted additional field surveys in the Shennongjia region to illustrate the outstanding universal value of Shennongjia World Natural Heritage Site using World Heritage criteria (ix) and (x), following the operational guidelines for the implementation of the World Heritage Convention. Results show that the heritage of Shennongjia offers an outstanding example of the ongoing ecological processes occurring in the development of intact subtropical mixed broad-leaved evergreen and deciduous forests in the Northern Hemisphere. This region presents a typical example of mountain altitudinal biological zones in the Oriental Deciduous Forest Biogeographical Province. Shennongjia is also a vital origin location for global temperate flora, and harbors the highest concentration of global temperate genera of
\end{abstract}

收稿日期: 2016-09-20; 接受日期: 2017-01-20

基金项目: 国家重点研发计划“遗产地生态保护与修复技术体系研究” (2016YFC0503303)和中国科学院野外站联盟项目“中国典型自然保护区保护成 效评估” (KFJ-SW-YW028)

* 通讯作者 Author for correspondence. E-mail: xie@ibcas.ac.cn 
trees. Moreover, the heritage of Shennongjia displays exceptional biodiversity and is a key habitat for numerous relic, rare, endangered and endemic species. The richness of deciduous woody species in Shennongjia is the highest in the world. Our study provides great insight into protecting, monitoring and managing the outstanding world heritage in the Northern Hemisphere.

Key words: mountain altitudinal zones; deciduous woody species; corridor, stepping stones, wildlife crossing; biological and ecological process; biodiversity and habitat

动植物多样性及其群落正在进行的生物生态 过程是人类赖以生存和发展的基础, 具有巨大的经 济、环境和社会公益价值(Chapin et al, 2000)。它不 仅为我们提供食物、能源和材料等基本需求, 同时 在水土保持、气候调节、干扰调节和生物控制等生 态系统功能方面具有不可替代的作用, 是生态系统 平衡与稳定的有力保障(Costanza et al, 1997), 更是 保证国民经济体系长期、稳定和可持续发展的前提 (Chapin et al, 2000)。生物多样性的丧失不仅会引起 食物链的缺损和不同物种之间生态关系的断裂 (Tilman et al, 2014), 导致其他物种的连锁性灭绝 (Lavergne et al, 2010), 而且还会导致生态系统功能 发生根本性的改变(Cardinale et al, 2012), 制约社会 经济的可持续发展, 威胁国家的生态安全(李文华, 2013)。

自然保护地是生物多样性及其生物生态过程 保护的最有效手段(Joppa et al, 2008; Pouzols et al, 2014), 几乎已成为所有国家和国际生物多样性保 护战略的核心部分(张琰等, 2015)。目前, 全球已建 有155,584处自然保护地, 覆盖了12.5\%的陆地表面 积(Watson et al, 2014; Shen et al, 2015)。为保护生物 多样性和生态系统功能, 截至2015年年底, 我国已 建立2,740处自然保护区(秦卫华等, 2017)。世界自然 遗产地是一定面积的具有一种或多种特定自然价 值的特殊区域, 是全球最具有保护价值的自然保护 地(Primack和马克平, 2010), 它强调全球突出普遍 价值的完整性及其在全球的唯一性(宋峰等, 2009; Xu et al, 2012)。截至2016年9月, 全球共有238处保 护地(其中包括35处自然和文化双遗产地)被列入 《世界自然遗产名录》, 我国有15处(其中4处为世 界自然和文化双遗产地) (马克平, 2016)。

华中山地是联结喜马拉雅-中-日植物区系的 桥梁, 也是西南与华东到台湾植物区系联系的桥头 堡。神农架世界自然遗产地地处华中山地, 以其丰 富的动植物多样性和独特的生物生态过程, 维持着
北亚热带山地生态系统的功能和稳定性。从19世纪 初开始, 国内外研究人员就对神农架世界自然遗产 地的地质地貌、动植物多样性和生态系统功能等进 行了大量的调查和研究工作(郑重等, 1997; 朱兆泉 和宋朝枢, 1999; 应俊生和陈梦玲, 2011)。这些工作 为深入挖掘神农架世界自然遗产地的全球突出普 遍价值奠定了基础。

本研究在收集整理神农架历史文献资料的基 础上, 基于我们对神农架地区长达近20年的调查研 究和数据积累, 依据“实施《世界遗产公约》操作指 南” (UNESCO World Heritage Centre, 2015), 从动植 物多样性及其栖息地、生物群落及其生物生态学过 程等方面, 分析论证了神农架世界自然遗产地的全 球突出普遍价值。

\section{1 材料和方法}

\section{1 研究区概况}

神农架世界自然遗产地主体位于湖北神农架 国家级自然保护区(神农架林区), 同时包括部分巴 东金丝猴国家级自然保护区(巴东县)区域(图1)。神 农架世界自然遗产地位于中国地势第二阶梯的东 部边缘, 为大巴山脉东段组成的中山地貌, 呈近东 西方向延伸, 地势西南高东北低, 峡谷纵横深切。 神农顶海拔3,106.2 m, 为大巴山脉主峰和湖北省的 最高点, 也是华中地区最高点(朱兆泉和宋朝枢, 1999)。受亚热带环流控制, 气候属北亚热带季风气 候, 常年温暖湿润, 为中国南部亚热带与北部暖温 带的气候过渡区域。年均气温 $12-17^{\circ} \mathrm{C}$, 极端最低气 温 $-31^{\circ} \mathrm{C}$, 极端最高气温 $43^{\circ} \mathrm{C}$, 年均降水量 700-2,700 mm。山体具有明显的垂直气候带, 从低 海拔到高海拔依次呈现出北亚热带、暖温带、温带、 寒温带的气候特点。土壤具有明显的自然垂直带, 从低到高依次为山地黄壤、山地黄棕壤、山地棕壤、 山地暗棕壤和山地灰化暗棕壤。神农架复杂的地形 和巨大的高差、多种土壤类型和气候条件, 孕育了 


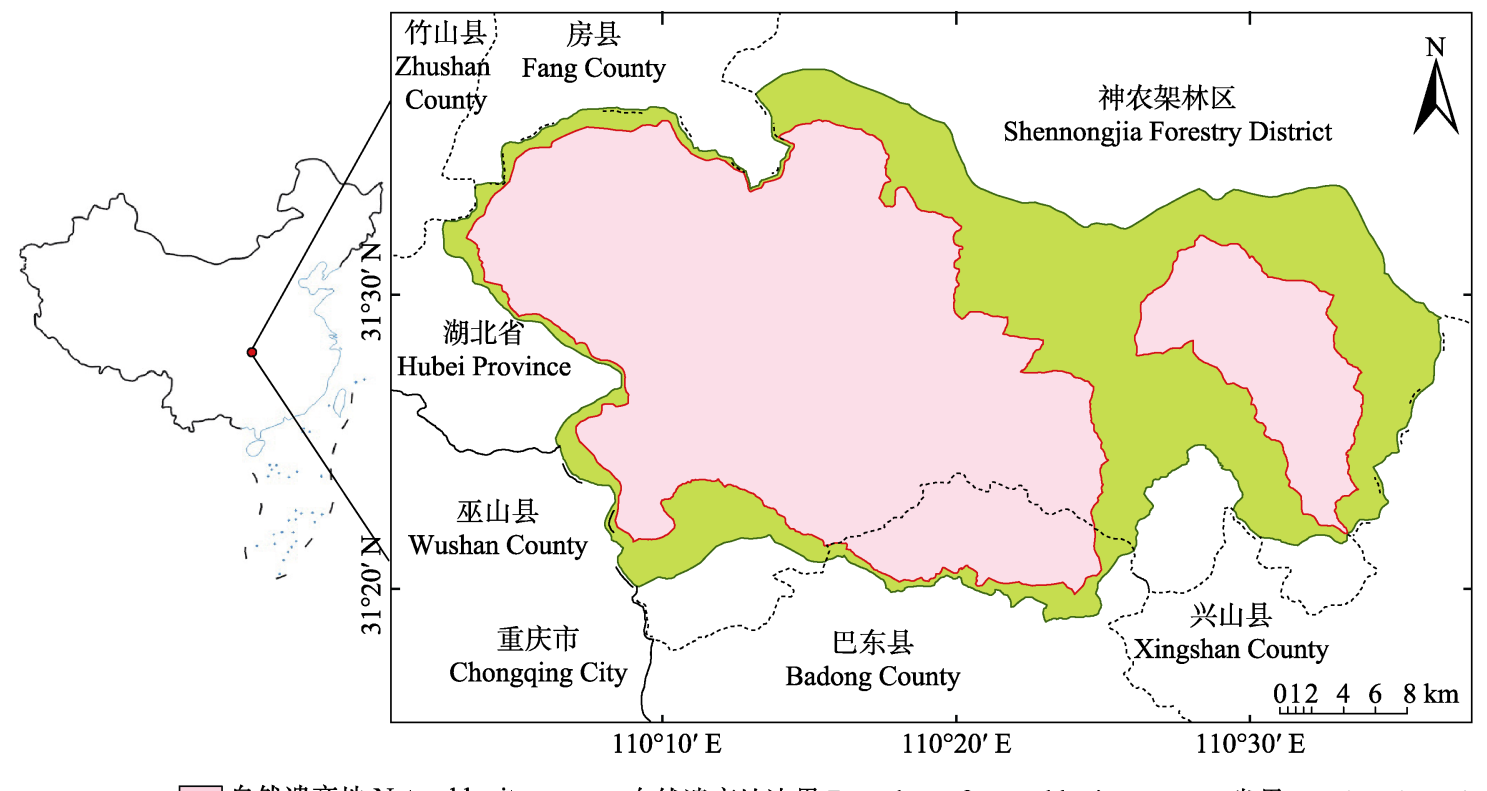

$\square$ 自然遗产地 Natural heritage $\square$ 自然遗产地边界 Boundary of natural heritage $\square$ 省界 Province boundary
$\square$ 缓冲区 Buffer zone

图1 神农架世界自然遗产地地理位置

Fig. 1 The map of Shennongjia World Natural Heritage Site

多样的栖息地类型和丰富的生物多样性。该地共有 11 个植被型和 50 个群系, 海拔从低到高 $2,700 \mathrm{~m}$ 的 落差内分布有完整的山地植被垂直带谱: 常绿榈叶 林、常绿落叶阔叶混交林、落叶阔叶林、针阔混交 林、针叶林、灌丛草甸(应俊生等, 1979; 郑重等, 1997)。其生态系统完整, 是华中地区面积最大的原 始森林分布区。

\section{2 研究方法}

\subsection{1 资料收集整理}

到目前为止，收集并整理了国内外学者公开发 表和出版的关于湖北神农架地质地貌、自然地理、 生物生态等方面的重要研究论文论著620篇(部)。 1888-1910年, 英国博物学家威尔逊20年间4次来神 农架考察, 出版了《自然科学家在中国西部》和《中 国一一园林之母》, 详细记载了神农架珍稀植物的 特征(Dosmann \& Tredici, 2003, 2005)。由其采集标 本并编著的《威尔逊植物志》已成为神农架最早的 里程碑式研究。1868年, 法国生物学家阿曼德·戴维 来神农架考察, 发表了《谭微道植物志》(王希群, 2007)。20世纪初以来, 中国科学家开展了对神农架 地质(赵志中和何培元, 1997; Zhu et al, 2008)、植物 (应俊生和陈梦玲, 2011)、动物(朱兆泉等, 1992; 李 义明等, 2005; Xiang et al, 2011)、气候(李文渏, 1993)、植被(贺金生等, 1998; 赵常明, 2002; 沈泽吴
等, 2004)、生态系统功能(春敏莉等, 2009; 罗璐等, 2011; 刘蕾等, 2012)等方面的研究, 先后出版了《神 农架植物》(中国科学院武汉植物研究所, 1980) 、

《鄂西植被研究》(班继德和漆根深, 1995)、《中国 神农架》(郑重等, 1997)、《神农架自然保护区科学 考察集》(朱兆泉和宋朝枢, 1999)等。这些成果是认 知神农架自然遗产价值的科学基础。

\subsection{2 野外调查}

(1)生物种类和资源普查。按照野外实地调查与 遥感解译相结合的原则, 根据自然地理区划, 将神 农架地区划分成若干个区域，在每个区域内设置一 定数量的考察样点或样线, 对区域内的动植物资源 进行普查。调查记录区域内不同生境条件下出现的 动植物物种、资源量及样方的面积大小。采集动植 物标本, 记录每份标本的地名、海拔、生境、采集 时间、采集人等。

(2)植被类型调查。按照普查与重点调查相结 合、点线面相结合的原则, 根据植被分布特点, 用 样方调查的方法, 按群系分类记录调查到的植被类 型。在2010-2013年间, 共调查了 260 个植物群落样 方。其中, 森林样方调查面积为 $20 \mathrm{~m} \times 20 \mathrm{~m}$, 记录 样方内的树种并测定每株的高度、枝下高、胸径和 冠幅, 记录林下灌木和草本种类并测量其高度、盖 度、冠幅和多度; 灌木样方大小为 $10 \mathrm{~m} \times 10 \mathrm{~m}$, 草 
本样方大小为 $5 \mathrm{~m} \times 5 \mathrm{~m}$ 。同时, 对调查过程中出现 的植被类型及农田(含居民点)等进行GPS定位, 测 量经纬度、海拔、坡度、坡向, 记录小地名、小地 形、地质条件与基岩、水分条件、干扰程度; 拍摄 反映群落特征的照片。

(3)植被垂直带谱的长期固定监测。沿海拔梯度 在不同的植被带分别设置不小于 $50 \mathrm{~m} \times 50 \mathrm{~m}$ 的固 定样地, 每隔5年进行乔木、灌木和草本监测。本文 采用2015年的监测数据。

(4)利用红外相机监测动物种类及其种群、栖息 地动态。2010-2011年在神农架世界自然遗产地内 按照 $2 \mathrm{~km} \times 2 \mathrm{~km}$ 的公里网格布设红外相机, 共布设 37台红外相机。相机设置在动物活动痕迹较多的地 点, 固定于树干上离地面50-80 cm处, 相机镜头与地 面基本平行, 要求相机捆绑牢固, 目视取景合理。 记录相机放置的日期、GPS位点、海拔、坡向、坡 度、植被类型、动物活动痕迹以及人为干扰等信息。

\subsection{3 数据整理与分析}

整理样方资料和调查数据及动植物标本鉴定 结果, 梳理神农架地区文献记录, 进行生物多样性 编目, 建立神农架世界自然遗产地高等植物、哺乳 动物、两栖动物、爬行动物、鸟类、昆虫、鱼类及 植被和生态系统类型的数据库。对照IUCN物种红 色名录(2014)、《濒危野生动植物种国际贸易公约》 (CITES) (2014)附录I和II、中国植被分类体系, 编制 并建立神农架世界自然遗产地珍稀濒危物种名录、 古老子遗物种名录、特有物种名录及植被类型。

\section{2 神农架世界自然遗产地的全球突出普遍 价值}

神农架世界自然遗产地位于中国地势第二阶 梯的东部边缘, 是长江和汉水的分水岭。因受亚热 带环流控制, 南北冷暖气团在此交汇, 使得它成为 中国南部亚热带与北部暖温带的过渡区域。与同一 生物地理省的同类世界自然遗产地(如黄山和日本 白神山)相比, 神农架世界自然遗产地在气候带、地 带性植被类型、生物多样性、垂直自然带谱等方面 具有不可替代性。神农架世界自然遗产地与白神山 (温带阔叶林区) 所处的气候带不同, 其地带性植被 类型(常绿落叶阔叶混交林)与黄山(常绿阔叶林)和 白神山(寒温带山毛榉(Fagus)林)不同。神农架世界 自然遗产地的生物多样性非常丰富, 且垂直自然带
谱更为完整。神农架世界自然遗产地保存了最为完 好的原始常绿落叶阔叶混交林, 拥有东方落叶林生 物地理省最完整的垂直带谱, 是世界温带植物区系 的集中发源地和全球落叶木本植物最丰富的地区, 代表了北亚热带动植物群落正在进行的生物生态过 程, 是生物多样性就地保护的最重要和突出的自然 栖息地, 在东方落叶林生物地理省具有不可替代性。

\section{1 具有保存完好的常绿落叶阔叶混交林和完整 的垂直带谱}

神农架世界自然遗产地保存了北半球最典型 的常绿落叶阔叶混交林。青藏高原的隆起使在副热 带高压控制下的亚热带形成了全球独一无二的东 亚季风型亚热带常绿阔叶林, 它既不同于地中海型 耐旱热的硬叶常绿林, 也不同于北半球同纬度的亚 热带、热带荒漠植被(中国科学院中国植被图编辑委 员会, 2007)。常绿落叶阔叶混交林是北亚热带的地 带性代表类型, 是暖温带落叶阔叶林向中亚热带常 绿阔叶林的过渡类型(谢宗强等, 2007)。较之东亚其 他亚热带区域, 神农架常绿落叶阔叶混交林为北 半球保存最为完好的常绿落叶阔叶混交林, 代表并 展示了常绿落叶阔叶混交林生态系统的生物生态 学过程。

神农架世界自然遗产地垂直高差达2,700 m, 既未遭受第四纪冰川的全面覆盖, 也免于蒙古-西 伯利亚大陆反气旋与寒流的严重侵袭, 又受到西南 与东南季风的浸润和从热带亚热带及暖温带山地 迁徙而来的植物成分的补充, 形成了海拔从低到高 完整的山地植被垂直带系统, 自下而上依次发育有 常绿阔叶林、常绿落叶阔叶混交林、落叶阔叶林、 针阔混交林、针叶林及亚高山灌从和草甸。在较小 的水平距离范围内浓缩了亚热带、暖温带、温带和 寒温带等生态系统类型, 在东方落叶林生物地理省 具有唯一性和代表性(Udvardy, 1975)。

\section{2 是世界温带植物区系的集中发源地和全球温 带分布属最集中的区域}

据统计, 中国温带分布属约有931属, 是世界 上最为集中的地区(吴鲁夫, 1964)。鄂西是温带植物 区系最丰富的地区，是世界温带植物区系的发源地， 是温带植物区系分化和发展的集散地(应俊生等, 1979; 应俊生，2001)。神农架世界自然遗产地分布 有温带分布属590属, 覆盖了中国温带分布属的 $63.3 \%$ 。因此, 神农架世界自然遗产地是全球温带分 
布属最集中的区域, 是温带植物分化、发展和集散 的重要地区(应俊生和陈梦玲, 2011)。

\section{3 是全球落叶木本植物最丰富的地区}

神农架世界自然遗产地有落叶木本植物 77 科 245属874种, 分别占该地区野生种子植物总科数的 $44.5 \%$ 、总属数的 $24.8 \%$ 和总种数的 $24.7 \%$ 。全球落 叶木本植物主要分布在欧洲、北美东部以及亚洲的 中国和日本(Yahner, 1995)。北美的温带落叶林物种 数多于欧洲, 其中美国大雾山国家公园被认为是北 美落叶木本植物种类最多的地区(Sayre, 1994)。据 IUCN世界遗产中心评估报告, 大雾山拥有全球温 带森林中最丰富的落叶树种, 约有200种落叶乔灌 木(Braun, 1950), 但远远低于神农架世界自然遗产 地的874种。日本的温带落叶林主要分布于日本中 部, 其中Ogawa森林保护区是日本温带落叶树种最 多的地区, 被誉为全球温带落叶木本最丰富的地区 之一 (Nakashizuka \& Matsumoto, 2002)。然而, Ogawa森林保护区拥有的落叶木本植物不足 200 种, 也远低于神农架世界自然遗产地。

\section{4 为北亚热带古老子遗、珍稀濒危和特有物种的} 关键栖息地

独特的地理位置和气候特征使神农架世界自 然遗产地拥有丰富的生物多样性, 成为众多古老子 遗、珍稀濒危、特有生物和模式标本的突出栖息地 和产地。神农架世界自然遗产地的植物区系在第三 纪前已基本形成, 有139科597属维管束植物起源于 第三纪之前, 分别占维管束植物总科、属的 $65.9 \%$ 和 $55.7 \%$, 其中 $95 \%$ 的中国特有属植物为单型属或者 寡型属。同时, 遗产地是巫山北鲵(Ranodon shihi)、 中国小鲵 (Hynobius chinensis) 和大鲵 (Andrias davidianus)等呈种间断裂分布的物种的重要栖息 地。这充分说明了神农架世界自然遗产地动植物区 系的古老性(费梁, 2006; 吴征镒, 2010; Mao et al,
2012)。遗产地有205种本地特有植物和 2 个本地特有 属(Deng et al, 2013), 以及1,793种中国特有植物(表 1), 是523种模式植物标本产地和世界上广泛引种 的珍稀、园艺物种的原生地(表2), 为植物系统学、 园艺学的科学圣地和研究热点地区。同时, 110 种植 物和48种动物被IUCN红色名录列为濒危级, 94种 植物和74种动物被收录在《濒危野生动植物种国际 贸易公约》(CITES) (表3, 4)。而且遗产地也是川金 丝猴湖北亚种(Rhinopithecus roxellana hubeiensis)的 唯一栖息地。

\section{3 神农架世界自然遗产地全球突出普遍价 值的保护管理}

由于地势险峻、交通封闭, 核心区域人为活动 较少，神农架世界自然遗产地较好地保持了原始的 自然状态。加之健全的法律保障、科学的保护规划 及高效的管理机制, 遗产地的生态系统、自然垂直 带谱、生物多样性及其栖息地与地貌景观等遗产资

\section{表1 神农架世界自然遗产地特有植物物种组成}

Table 1 Statistics of plant species endemic to Shennongjia World Natural Heritage Site

\begin{tabular}{|c|c|c|}
\hline $\begin{array}{l}\text { 门类 } \\
\text { Category }\end{array}$ & $\begin{array}{l}\text { 神农架特有种 } \\
\text { Endemic to Shennongjia }\end{array}$ & $\begin{array}{l}\text { 中国特有种 } \\
\text { Endemic to China }\end{array}$ \\
\hline 硕类植物 Pteridophyta & 9 & 86 \\
\hline 裸子植物 Gymnospermae & 1 & 31 \\
\hline 被子植物 Angiospermae & 195 & 1,676 \\
\hline 总计 Total & 205 & 1,793 \\
\hline
\end{tabular}

表2 神农架世界自然遗产地的模式标本植物组成

Table 2 Statistics of the plants of type specimens in Shennongjia World Natural Heritage Site

\begin{tabular}{llll}
\hline 门类 Category & 科 Family & 属 Genera & 种数 Species \\
\hline 葓类植物 Pteridophyta & 8 & 14 & 22 \\
裸子植物 Gymnospermae & 2 & 4 & 5 \\
被子植物 Angiospermae & 78 & 245 & 496 \\
总计 Total & 88 & 263 & 523 \\
\hline
\end{tabular}

表3 神农架世界自然遗产地珍稀濒危植物物种组成

Table 3 Statistics of rare and endangered plants in Shennongjia World Natural Heritage Site

\begin{tabular}{|c|c|c|c|c|c|c|c|}
\hline \multirow[t]{2}{*}{ 门类 Category } & \multicolumn{3}{|c|}{ IUCN Red List (2014) } & \multicolumn{2}{|l|}{ CITES (2014) } & \multicolumn{2}{|c|}{$\begin{array}{l}\text { 国家保护野生植物名录 } \\
\text { List of national protected plants }\end{array}$} \\
\hline & 极危(CR) & 濒危(EN) & 易危(VU) & I 级Appendix I & II 级Appendix II & I 级Class I & II 级Class II \\
\hline 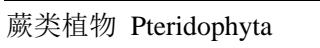 & 0 & 2 & 4 & 0 & 0 & 0 & 1 \\
\hline 裸子植物 Gymnospermae & 0 & 0 & 5 & 2 & 0 & 2 & 7 \\
\hline 被子植物 Angiospermae & 7 & 31 & 61 & 14 & 78 & 18 & 139 \\
\hline 合计 Total & 7 & 33 & 70 & 16 & 78 & 20 & 147 \\
\hline
\end{tabular}


表 4 神农架世界自然遗产地珍稀濒危动物物种组成

Table 4 Statistics of rare and endangered animals in ShennongjiaWorld Natural Heritage Site

\begin{tabular}{|c|c|c|c|c|c|c|}
\hline \multirow[t]{2}{*}{ 门类 Class } & \multirow[t]{2}{*}{ IUCN (2014) } & \multicolumn{2}{|c|}{ CITES (2014) } & \multirow[t]{2}{*}{$\begin{array}{l}\text { 中国物种红色名录(2015) } \\
\text { China Species Red List (2015) }\end{array}$} & \multicolumn{2}{|c|}{$\begin{array}{l}\text { 国家重点保护野生动物名录(1988) } \\
\text { National Key Protected Wild Animals List (1988) }\end{array}$} \\
\hline & & $\mathrm{I}$ & II & & I & II \\
\hline 哺乳类 Mammals & 16 & 8 & 5 & 19 & 4 & 11 \\
\hline 鸟类Birds & 19 & 4 & 53 & 21 & 3 & 61 \\
\hline 爬行类 Reptiles & 3 & 0 & 2 & 14 & 0 & 0 \\
\hline 两栖类 Amphibians & 8 & 1 & 1 & 9 & 0 & 2 \\
\hline 鱼类 Fishes & 2 & 0 & 0 & 10 & 0 & 0 \\
\hline 总计 Total & 48 & 13 & 61 & 73 & 7 & 74 \\
\hline
\end{tabular}

源得以完整保存, 遗产地的完整性和突出普遍价值 保持完好。为了进一步保护遗产地的全球突出普遍 价值, 建议采取相应措施加强保护。

\section{1 构建“廊道一踏脚石一通道”连通生境的镶嵌式 格局}

在遗产地濒危植物分布较集中的区域设立珍 稀濒危植物就地保护区, 采取适当的人为干预措施 以提高珍稀濒危植物结实率, 促进其种群更新与复 壮。在山地植被垂直带谱分布比较集中的九冲河、 阴峪河、长坪河和羊圈河等流域设立长期固定监测 样地, 定期监测常绿落叶阔叶混交林生态系统及其 垂直分异规律和生态学过程; 同时, 严格保护山地 植被垂直带谱集中分布区，禁止砍伐。在相互隔离 的东西两片区域之间，构建“廊道一踏脚石-通道”的 镶嵌式格局, 实现野生动植物的交流和生态系统功 能的连通。

\section{2 遗产地分区保护}

对遗产地按禁限区和展示区进行分区管理。其 中, 禁限区内必须维持原始自然状态, 可适当开展 观光游览和科教旅游活动; 展示区可安置必需的游 客服务设施与基础设施, 限制与风景游赏无关的建 设项目。同时, 在遗产地外围设置起保护作用的缓 冲区域, 维持遗产地生态系统、生物多样性和自然 景观的完整性。

\section{3 建立联合工作的长效机制}

遗产地保护与社区综合协调发展是遗产地保 护和管理成效的关键。建议成立世界自然遗产综合 管理委员会, 建立神农架世界自然遗产地联合工作 的长效机制。综合管理委员会和社区通过参与式管 理模式, 确保遗产地的完整性。同时, 对遗产地内 的居民实施异地搬迁, 有效保护自然资源及野生动 植物栖息地。通过宣传、教育和培训，使缓冲区社
区群众掌握保护的规范、方式和技术，主动参与到 自然遗产的管理和保护行动中, 实现遗产地管理方 和社区对遗产地的共同管理。

\section{参考文献}

Ban JD, Qi GS (1995) Vegetation in Western Hubei. Huazhong University of Science and Technology Press, Wuhan. (in Chinese) [班继德, 漆根深 (1995) 鄂西植被研究. 华中理 工大学出版社, 武汉.]

Braun EL (1950) Deciduous Forests of Eastern North America. Macmillan, New York.

Cardinale B, Duffy E, Gonzalez A, Hooper DU, Perrings C, Venail P, Narwani A, Mace GM, Tilman D, Wardle DA, Kinzig AP, Daily GC, Loreau M, Grace JB, Larigauderie A, Srivastava DS, Naeem S (2012) Biodiversity loss and its impact on humanity. Nature, 486, 59-67.

Chapin FS, Zavaleta ES, Eviner VT, Naylor RL, Vitousek PM, Reynolds HL, Hooper DU, Lavorel SL, Sala OE, Hobbie SE, Mack MC, Diaz S (2000) Consequences of changing biodiversity. Nature, 405, 234-242.

Chun ML, Xie ZQ, Zhao CM, Fan DY, Xu XW, Ping L (2009) Litter production and nutrient characteristics of Abies fargesii natural forest in Shennongjia Nature Reserve, Hubei, China. Chinese Journal of Plant Ecology, 33, 492-498. (in Chinese with English abstract) [春敏莉, 谢宗强, 赵常明, 㚞大勇, 徐新武, 平亮 (2009) 神农架巴山冷杉天然林调 落量及养分特征. 植物生态学报, 33, 492-498.]

Costanza R, Arge R, Groot RD, Farbe S, Grasso M, Hannon B, Limburg K, Naeem S, Oneill RV, Paruelo Jose, Raskin RG, Sutton P, Belt MA (1997) The value of the world's ecosystem services and natural capital. Nature, 387, 253-260.

Deng T, Kim C, Zhang DG, Zhang JW, Li ZM, Nie ZL, Sun H (2013) Zhengyia shennongensis: a new bulbiliferous genus and species of the nettle family (Urticaceae) from Central China exhibiting parallel evolution of the bulbil trait. Taxon, 62, 89-99.

Dosmann M, Tredici PD (2003) Plant introduction, distribution, and survival: a case study of the 1980 Sino-American Botanical Expedition. BioScience, 6, 588-597. 
Dosmann M, Tredici PD (2005) The Sino-American Botanical Expedition of 1980: a retrospective analysis of success. Hortscience, 2, 302-303.

Editorial Committee of Vegetation Atlas of China, Chinese Academy of Sciences (2007) 1: 1000000 Vegetation Atlas of People's Republic of China. Geological Publishing House, Beijing. (in Chinese) [中国科学院中国植被图编辑 委员会 (2007) 中华人民共和植被图(1: 1000000). 地质 出版社, 北京.]

Fei L (2006) Fauna of China, Amphibia. Vol.1. Science Press, Beijing. (in Chinese) [费梁 (2006) 中国动物志 - 两栖纲 (上卷). 科学出版社, 北京.]

He JS, Chen WL, Liu F (1998) Study on the sprouting process of Fagus engleriana in Shennongjia Mountains. Acta Phytoecologica Sinica, 22, 385-391. (in Chinese with English abstract) [贺金生, 陈伟烈, 刘峰 (1998) 神农架地区米心 水青冈萌枝过程的研究. 植物生态学报, 22, 385-391.]

Joppa LN, Loarie SR, Pimm SL (2008) On the protection of protected areas. Proceedings of the National Academy of Sciences, USA, 105, 6673-6678.

Lavergne S, Mouquet N, Thuiller W, Ronce O (2010) Biodiversity and climate change: integrating evolutionary and ecological responses of species and communities. Annual Review of Ecology, Evolution, and Systematics, 41, 321350.

Li WH (2013) Contemporary Ecology Research in China. Science Press, Beijing. (in Chinese) [李文华 (2013) 中国当代 生态学研究. 科学出版社, 北京.]

Li WY (1993) Study on Vegetation and Environment in Late Quaternary in North and Middle Subtropical Region, China. Ocean Press, Beijing. (in Chinese) [李文猗 (1993) 中国 北、中亚热带晚第四纪植被与环境研究. 海洋出版社, 北京.]

Li YM, Liao MY, Yu J, Yang JY (2005) Effects of annual change in group size, human disturbances and weather on daily travel distance of a group in Sichuan snub-nosed monkey (Rhinopithecus roxellana) in Shennongjia Nature Reserve, China. Biodiversity Science, 13, 432-438. (in Chinese with English abstract) [李义明, 廖明尧, 喻杰, 杨 敬元 (2005) 社群大小的年变化、气候和人类活动对神农 架自然保护区川金丝猴日移动距离的影响. 生物多样性, 13, 432- 438.]

Liu L, Shen GZ, Chen FQ, Luo L, Xie ZQ, Yu J (2012) Dynamic characteristics of litterfall and nutrient return in four types of forests along an elevational gradient in Shennongjia, China. Acta Ecologica Sinica, 32, 2142-2149. (in Chinese with English abstract) [刘蕾, 申国珍, 陈芳清, 罗璐, 谢宗强, 喻杰 (2012) 神农架海拔梯度上4种典型森林调 落物现存量及其养分循环动态. 生态学报, 32, 21422149.]

Luo L, Shen GZ, Xie ZQ, Zhou LG (2011) Components of soil respiration and its temperature sensitivity in four types of forests along an elevational gradient in Shennongjia, China.
Chinese Journal of Plant Ecology, 35, 722-730. (in Chinese with English abstract) [罗璐, 申国珍, 谢宗强, 周利光 (2011b) 神农架海拔梯度上4种典型森林的土壤呼吸组分 及其对温度的敏感性. 植物生态学报, 35, 722-730.]

Ma KP (2016) Conservation of world natural heritage should be ensured and its contribution to local sustainable development promoted. Biodiversity Science, 24, 861-862. (in Chinese) [马克平 (2016) 世界自然遗产既要加强保护也 要适度利用. 生物多样性, 24, 861-862. ]

Mao KS, Milne RI, Zhang LB, Peng YL, Liu JQ, Thomas P, Mill PR, Renner SS (2012) Distribution of living Cupressaceae reflects the breakup of Pangea. Proceedings of the National Academy of Sciences, USA, 109, 7793-7798.

Nakashizuka T, Matsumoto Y (2002) Diversity and Interaction in A Temperate Forest Community: Ogawa Forest Reserve of Japan. Springer, Berlin.

Pouzols FM, Toivonen T, Minin ED, Kukkala AS, Kullberg P, Kuustera J, Lehtomaki J, Tenkanen H, Verburg PH, Moilanen A (2014) Global protected area expansion is compromised by projected land-use and parochialism. Nature, 516, 383-386.

Primack RB, Ma KP (2010) Essentials of Conservation Biology. Science Press, Beijing. (in Chinese) [Primack RB, 马 克平 (2010) 保护生物学简明教程. 高等教育出版社, 北京.]

Qin WH, Li ZL, Wang Z, Qian ZD, Zhou DQ, Zhang HN, Zhang JN (2017) Overview of China Nature Reserve. Life World, (2), 10-35. (in Chinese) [秦卫华, 李中林, 王智, 钱者东, 周大庆, 张吴楠, 张建亮 (2017) 中国自然保护 区大观. 生命世界, (2), 10-35.]

Sayre AP (1994) Temperate Deciduous Forest. Twenty-First Century Books, New York.

Shen GZ, Pimm SL, Feng CY, Ren GF, Liu YP, Xu WT, Li JQ, Si XF, Xie ZQ (2015) Climate change challenges the current conservation strategy for the giant panda. Biological Conservation, 190, 43-50.

Shen ZH, Hu HF, Zhou Y, Fang JY (2004) Altitudinal patterns of plant species diversity on the southern slope of Mt. Shennongjia, Hubei, China. Biodiversity Science, 12, 99107. (in Chinese with English abstract) [沈泽吴, 胡会峰, 周宇, 方精云 (2004) 神农架南坡植物群落多样性的海 拔梯度格局. 生物多样性, 12, 99-107.]

Song F, Zhu JJ, Li YF (2009) Retrospection on the "integrity" principle of world heritage-review of the 4 concepts of the Operational Guidelines for the Implementation of the World Heritage Convention. Chinese Landscape Architecture, (5), 14-18. (in Chinese with English abstract) [宋峰, 祝佳杰, 李雁飞 (2009) 世界遗产“完整性”原则的再思考一一基 于《实施世界遗产公约的操作指南》中 4 个概念的辨析. 中 国园林, (5), 14-18.]

Tilman D, Isbell F, Cowles JM (2014) Biodiversity and ecosystem functioning. Annual Review of Ecology, Evolution, and Systematics, 45, 471-493. 
Udvardy MD (1975) A classification of the biogeographical provinces of the world. INCN paper No. 18. pp. 20-21. Morges, Switzerland. http://agris.fao.org/agris-search/search.do?recordID=XF2016014050/. (accessed on 2016-12-19)

UNESCO World Heritage Centre (2015) Operational Guidelines for the Implementation of the World Heritage Convention. http://whc.unesco.org/en/guidelines/. (accessed on 201612-19)

Wang XQ, Ma LY, Chen FJ, Jia JL, Guo BX (2007) An important exploration undertaking in Chinese modern science history: the first exploration in Shennongjia of Hubei Province in 1940s. Journal of Beijing Forestry University, 6(2), 48-53. (in Chinese with English abstract) [王希群, 马履一, 陈发菊, 贾京黎, 郭保香 (2007) 中国现代科学史上的一 次科学考察壮举一一记 20 世纪 40 年代首次对湖北神农架 的探察. 北京林业大学学报, 6(2), 48-53.]

Watson JE, Dudley N, Segan DB, Hockings M (2014) The performance and potential of protected areas. Nature, 515, $67-73$.

Wu ZY (2010) Chinese Floristic Geography. Science Press, Beijing. (in Chinese) [吴征镒 (2010) 中国种子植物区系 地理. 科学出版社, 北京.]

Wuhan Institute of Botany, Chinese Academy of Sciences (1980) Plants of Shennongjia. Hubei People’s Press, Wuhan. (in Chinese) [中国科学院武汉植物研究所 (1980) 神农架 植物. 湖北人民出版社, 武汉.]

Wulff EB (Translated by Zhong CX, Lu DA, Shen ZA, Hong BG, Wu YS, Yao ZH, Zhou HB) (1964) Historical Plant Geography. Science Press, Beijing. (in Chinese) [吴鲁夫 (仲崇信, 陆定安, 沈祖安, 洪必恭, 吴玉树, 姚中和, 周 鸿涁译) (1964) 历史植物地理学. 科学出版社, 北京.]

Xiang ZF, Yu Y, Yang M, Yang JY, Liao MY, Li M (2011) Does flagship species tourism benefit conservation? A case study of the golden snub-nosed monkey in Shennongjia National Nature Reserve. Chinese Science Bulletin, 56, 25532558.

Xie ZQ, Shen GZ, Fan DY, Xiong GM, Zhang M (2007) The curiosity in the remote mountains and forest-National Field Station for Forest Ecosystems in Shennongjia (NFSFES). Life World, (10), 18-23. (in Chinese) [谢宗强, 申国珍, 樊大勇, 熊高明, 张㨫 (2007) 深山老林育奇菂 - — 湖北神农架森林生态系统国家野外科学观测研究站. 生命世界, (10), 18-23.]

Xu XL, Yang ZP, Saiken A, Rui S, Liu XY (2012) Natural Heritage value of Xinjiang Tianshan and global comparative analysis. Journal of Mountain Science, 9, 262-273.

Yahner RH (1995) Eastern Deciduous Forests: Ecology and Wildlife Conservation. University of Minnesota Press, Minneapolis.

Ying TS (2001) Species diversity and distribution pattern of seed plants in China. Biodiversity Science, 9, 393-398. (in Chinese with English abstract) [应俊生 (2001) 中国种子
植物物种多样性及其分布格局. 生物多样性, 9, 393-398.]

Ying TS, Chen ML (2011) Plant Geography of China. Shanghai Scientific \& Technical Publishers, Shanghai. (in Chinese) [应俊生, 陈梦玲 (2011) 中国植物地理. 上海科学 技术出版社, 北京.]

Ying TS, Ma CG, Zhang ZS (1979) Vegetation and flora of Shennongjia region in western Hubei. Acta Phytotaxonomica Sinica, 3, 41-60. (in Chinese with English abstract) [应俊生, 马成功, 张志松 (1979) 鄂西神农架地区的植 被和植物区系. 植物分类学报, 3, 41-60.]

Zhang Y, Liu J, Zhu CQ (2015) IUCN Green List of Protected Areas: introduction, progress, opportunities and challenges for protected areas in China. Biodiversity Science, 23, 437-439. (in Chinese with English abstract) [张琰, 刘静, 朱春全 (2015) 自然保护地绿色名录: 内容、进展及为中 国自然保护地带来的机遇和挑战. 生物多样性, 23，437439.]

Zhao CM (2002) Vegetation of Shennongjia Mountainous Region and Its Plant Species Diversity and Vertical Distribution Pattern-Addictive to Discussion About the Vegetation Zonation in Middle and Northern Subtropical Subzone in China. PhD dissertation, Institute of Botany, Chinese Academy of Sciences, Beijing. (in Chinese with English abstract) [赵常明 (2002) 神农架植被及其生物多样性与垂 直分布格局——兼论中国中、北亚热带植被带的划分. 博 士学位论文, 中国科学院植物研究所, 北京.]

Zhao ZZ, He PY (1997) Quaternary Glaciation and Environment in Shennongjia. Geological Publishing House, Beijing. (in Chinese) [赵志中，何培元 (1997) 神农架第四纪冰期 与环境. 地质出版社, 北京.]

Zheng Z, Zhan YH, Xie JL (1997) Shennongjia, China. Hubei Science and Technology Publishing House, Wuhan. (in Chinese) [郑重，詹亚华，谢继伦 (1997) 中国神农架. 湖 北科学技术出版社, 武汉.]

Zhu C, Chen X, Zhang GS, Ma CM, Zhu Q, Li ZX, Xu WF (2008) Spore-pollen-climate factor transfer function and paleoenvironment reconstruction in Dajiuhu, Shennongjia, Central China. Chinese Science Bulletin, 53(Suppl.), 42-49.

Zhu ZQ, Hu ZL, Yang QR, He DG, Li JP (1992) The number distribution and population structure of golden monkey in Shennongjia Natural Reserve. Journal of Central China Normal University, 3, 79-82. (in Chinese with English abstract) [朱兆泉，胡振林，杨其仁，贺德贵，李巨平 (1992) 神农架自然保护区金丝猴数量、分布及种群结构. 华中师 范大学学报, 3, 79-82.]

Zhu ZQ, Song ZS (1999) Scientific survey of Shennongjia Nature Reserve. China Forestry Publishing House, Beijing. (in Chinese) [朱兆泉, 宋朝枢 (1999) 神农架自然保护区 科学考察集. 中国林业出版社, 北京.]

(责任编委：沈泽吴＼cjkstart责任编辑：黄祥忠) 